UDC 355.41

\title{
EXPERIMENTAL INVESTIGATION OF IMPACT OF INJURY MEASURES ON THE PROTECTION SCREENS OF COMBAT ARMOURED VEHICLES
}

\author{
V.O. Dachkovskyi, \\ I.P. Datsenko, \\ V.I. Kotsiuruba, \\ O.D. Yalnytskyi, \\ O.L. Holda, \\ O.M. Nedilko, \\ A.M. Syrotenko \\ National Defense University of Ukraine named after Ivan Chernyakhovsky, \\ 28, Povitroflotskiy avenu, Kyiv, Ukraine
}

DOI: $10.32347 / 2410-2547.2020 .104 .117-135$

\begin{abstract}
In order to evaluate the relative properties of the protective screen to the striking energy of the means of defeat, an experimental study was conducted, which allowed to test the hypothesis regarding the protection of the combat armoured vehicles against the means of defeat which, under the action of kinetic energy, destroy the armoured obstacle. Based on the data obtained during the experimental study, a mathematical model was constructed that describes the punching momentum of the protective screen. The use of this model makes it possible to calculate the energy losses caused by deformation and destruction of the obstacle. Built as a result of the multifactor experiment, the regularity of the impact of the means of defeat on the protective screen takes into account the speed of the means of defeat, the angle of encounter of the means of defeat with the protective screen, the thickness of the front and back layer and the hardness of the means of defeat.
\end{abstract} model.

Keywords: Combat armoured vehicles, protective screens, experimental study, mathematical

1. Introduction. Carrying out experimental studies concerning the security of combat armored vehicles (CAV) against firearms is crucial to substantiate the feasibility of using additional CAV protective screens. Tests are conducted to evaluate the effectiveness of the protection of the finished specimens, during which firearms or the means of imitation of firearms are used. Most often, such tests are performed as experiments to further validate the sample to ensure that the CAV sample withstands certain effects or to verify the claimed sample characteristics.

Therefore, the purpose of laboratory testing is to obtain useful information for assessing the relativity of persistent or weak properties to the effects of firearms on the elements of the sample (system). Laboratory tests are the basis for evaluating changes in the properties of elements that are not sensitive to the effects of the firearms lesion, as well as for getting empirical data about the

(C) Dachkovskyi V.O., Datsenko I.P., Kotsiuruba V.I., Yalnytskyi O.D., Holda O.L.,

Nedilko O.M., Syrotenko A.M. 
behaviour of many elements critical of the firearms lesion. In addition, they are linked to test methods that can serve for more effectively align of requirements to the stability of remedies with other requirements which are presented to the providers of protection means.

\section{Problem Formulation}

Given the fact that experimental studies require a considerable investment of time and money, so in the study of these phenomena most often use a stochastic approach, which abstracts from a number of factors. In this case, experimental and statistical methods of research are applied, in which real processes are considered as processes of probability, and the object of study is represented as a cybernetic system (black box), which is investigated by means of mathematical modelling [1]. Herewith about the functioning of the system is judged by its reaction $Y$ (baseline, response) at the output of the system when it causes certain influences $X$ (factors) at its input (fig. 1).

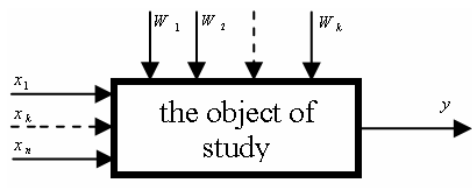

Fig. 1. The system of "Black box", the model of the object of study

For this purpose, we obtain a mathematical model of the process under study that adequately describes the relationship of process results (baseline indicators of $y$ ) to external influences (input factors of $x$ ).

It does not deny the possibility of further investigation of internal phenomena, but also generalizes information for much deeper disclosure of the cause-and-effect links in the processes that take place. Inasmuch as each of the responses is related to the input factors of the objectively existing dependency. Equation of state of the system, which, of course, is unknown. But, based on observations of the system's appeal , namely, the correspondence of the output indicators to the input at each point in time, the equation of state can be approximated by another function of the form [2].

$$
Y=B_{0}+\sum_{1 \leq i \leq k} B_{i} X_{i}+\sum_{1 \leq i<l \leq k} B_{i l} X_{i} X_{l}+\sum_{1 \leq i \leq k} B_{i i} X_{i}^{2}+\ldots
$$

where $Y$ an indicator of the process under study; $X_{i}$ - factors affecting the process under study; $B$ - regression equation coefficients; $B_{0}, B_{i} B_{i l} B_{i i}-$ polynomial coefficients; $k$-number of independent variables.

This regression equation is a polynomial model in the form of a Taylor series segment that describes well the function response of the local plane of the factor space and is convenient to use due to the versatility and comparative simplicity of their methods of construction based on experimental data [3].

The analysis of scientific studies showed that in the work [4], the results of the analysis of armoured machine body are given. The problems of providing an adequate level of ballistic and mine resistance are identified. The combined nature of the causes is due to the welding of steels used in the production and structural features of a number of housings, but it is not specified exactly how to increase the ballistic stability of the CAV housings in this work. In the dedicated 
work [5] on numerical modeling of process of penetration of protective ceramic elements with different design, the effectiveness of the developed protective ceramic elements for the protection of CAV was confirmed. But in this work is not specified as a means of defeat loses energy characteristics when breaking through an armour obstacle. The paper [6] presents a finite element model based on data obtained as a result of dynamic and static testing of composite materials to predict the response and behavior of failure of hybrid plates at low shock load. In this study, the impact of the velocity of the impactor, the angle of its incidence, and the thickness of the impactor were taken into account, but the hardness of the impactor was not taken into account and damaged obstacles were not investigated. In the work [7] that is devoted to increasing the level of protection of multi-purpose design vehicles, many variants of technical solutions for increasing the level of ballistic protection were proposed. The results of observations on vulnerable sections of vehicles from small firearms are presented, but it is not determined how to increase the level of protection against the means of damage.

That is, in these works [4-7] are not defined how the means of lesion will lose kinetic energy depending on the velocity, the angle of encounter with the protective screen, the thickness of the face and the rear layer of the protective screen, and the hardness of the means of lesion.

Therefore, the purpose of this article is to elucidate the results of an experimental study of the effect of the means of lesions on the protective screens of the CAV and to build a mathematical model based on experimental studies of energy loss by the means of lesion during the break of the protective screens of the CAV.

\section{Experimental study}

\subsection{Experimental equipment}

To evaluate the stability of the protective screen, the technique of investigation of the parameters of the breakdown with the registration of the shock pulse, which allows to carry out of rapid assessment of the resistance of materials to deformation and fracture during cross-cutting. [8-9]. However, it is possible to obtain a quantitative assessment of the stability of the material of the armor obstacle design to the breakdown, taking into account the conditions of interaction, physical and mechanical properties and geometric parameters of the impactor and obstacle. The essence of the technique lies in the fact that the obstacle samples are broken through by the impactor, so that the pendulum is given a shock impulse, which causes the deviation of the latter from the equilibrium position by the value $L$, which can calculate the energy losses caused by the deformation and destruction of the obstacle fig. 2 .

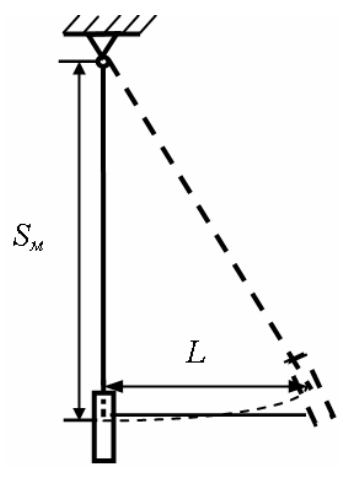

Fig. 2. Schema of ballistic pendulum 
Bulletproof resistance studies were conducted in the ballistic track of the Weapons Scientific Testing Laboratory and special protective materials in accordance with the requirements [10] of the experimental setup (fig. 3) [11].

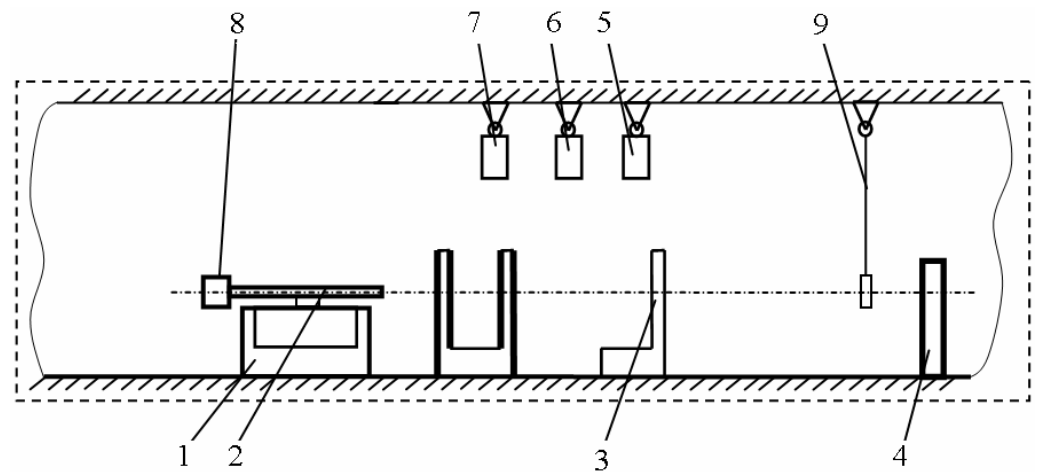

Fig. 3. Schema of ballistic installation:

1 - ballistic barrel mounting stand; 2 - barrel, 3 - velocity determination device, 4 - box, 5 illumination level determination device, 6 - noise level recording device, 7 - temperature recording sensor, 8 - duct pressure sensor in the barrel channel, 9 - ballistic pendulum

In doing so, a ballistic pendulum weighing $M_{\sigma}$ having the length of the pendulum from the point of hit of the ball in the sample to the axis of the swivel was used $S_{M}$ (fig.1). The pendulum was suspended from the ceiling in the ball holder of the ballistic track. The firing was carried out from a ballistic weapon by single-shots, mounted in a special device fastening of the product. The impactor was accelerated with the powder gases through the ballistic barrel channel, which at speeds of $300-900 \mathrm{~m} / \mathrm{s}$. interacted with an obstacle that was fixed on the ballistic pendulum. After the breaking through, he fell into the "unobstructed catcher". Shots were made with the help of an electro trigger. The velocity of the bullet was measured by the optoelectronic measuring complex IBX - 731.3, located at a distance of $2.5 \mathrm{~m}$ from the cut of the barrel. The distance from the section of the ballistic barrel to the point of defeat of the sample, which is rigidly fixed on the ballistic pendulum, was $10 \mathrm{~m}$.

To ensure the free passage of the impactors to the ballistic pendulum with simultaneous cutting off of the powder gases, special cut-offs are used to prevent them from influencing the sample fixed to the pendulum.

The study was conducted under the following conditions:

ambient temperature 0C $20 \pm 5$

relative humidity, $\%$ not more than 80

atmospheric pressure, $\mathrm{kPa} 87-107$

The object of the test is selected, proposed in the paper [12] protective screen fig. 4, the front and back layer of which is made of BT70SH steel and 10 $\mathrm{mm}$ thick porous AlSi7 cast aluminum is selected as the porous material. 
As an impactor was used a cylindrical device with rounded ends with a diameter of $15 \mathrm{~mm}$ and a length of $40 \mathrm{~mm}$ made of $\mathrm{y} 8 \mathrm{~A}$ steel.

Before the research the ballistic pendulum was calibrated. For this purpose, a non-penetrating indenter shot was used, which is used in the study. In this case, all the energy of the ball is spent on the deflection of the pendulum from an equilibrium state. Indenters and sample BT70SH by weight $M_{n}$ were used for calibration. All shots were carried out normal to the plane of the


Fig. 4. Protective screen CAV:

1 - the front layer, 2 - the back layer, 3 - the porous material, 4 - elastic elements specimen. The thickness of the specimen was chosen to ensure that it was not punched. The following ratio was used to determine the calibration factor for each shot

$$
k_{n i}=\left(m V_{2,5}\right)\left(S_{p}\right)^{-1},
$$

where $k_{n i}$ the calibration factor of the ballistic pendulum for each shot; $m$ mass of the intender, $\mathrm{kg} ; V_{2,5}$ speed of the intender at a distance of $2.5 \mathrm{~m}$ from the cut of the barrel, $\mathrm{m} / \mathrm{s} ; S_{p}$ the magnitude of the deviation of the pendulum from its equilibrium state after the indenter is hit in the sample, $\mathrm{m}$.

Three series of experiments were carried out to determine the calibration factor, taking into account different speeds of the intender. The values of the calibration coefficients for each shot were calculated by the average value of the calibration coefficient equal to

$$
k_{n}=\left(\sum_{i=1}^{N} k_{n i}\right)(N)^{-1} .
$$

The positioning of the ballistic barrel, the speedometer and the ballistic pendulum was constant, changing only the angle of inclination of the test specimen in accordance with the plan of the experimental study [13].

\subsection{Construction of mathematical model}

In order to evaluate the relative properties of the protective screen to the striking energy of the means of lesion, in the first stage of the study experimental tests were conducted which became the basis for obtaining empirical data on the behavior of many elements critical to the kinetic energy of the means of lesions.

The data obtained in the experimental study allowed us to test the hypothesis regarding the protection of $\mathrm{CAV}$ from the defeat agents, which under the action 
of kinetic energy destroys the armor obstruction, thereby causing premature failure of the CAV [14].

Previous studies have shown that the kinetic energy parameters of the means of defeat in one way or another affect the stability of the armoured obstacle, which leads to its destruction. Eventually leads to failure of the CAV. The basis of this nature of influence is a complex of physical phenomena that accompany the process of destruction of the armoured obstacle.

In order to calculate the model, information about the value of the response, which is investigated in the selected area of the factor space, is accumulated during the experiment. The most effective way of doing this is through an active experiment on the basis of multi-factor planning [15].

Planning a multifactorial experiment involves choosing the type of mathematical model. Insomuch as the real nature of the processes that occur under the influence of the lesion on the CAV in general is largely unknown then it is quite difficult to build a model adequate to the real process in advance. In this case, it would be most rational to use a priori information on similar studies.

First of all, it is about choosing a model class [8], namely about choosing a function

$$
M(y)=f\left(x_{1}, x_{2}, \ldots, x_{k}\right),
$$

where $y$ indicator of the process under study (response); $x_{1}, x_{2}, \ldots, x_{k}$ variable factors.

As stated in the works $[1-3,8,13-15]$, in the study of a large group of technical processes, it is better to use as a specified function step series, or rather segments of step series - algebraic polynomials. On the one hand, these are fairly simple equations, in terms of mathematical processing, and on the other hand, there is a high probability of obtaining an adequate model.

The next step is to choose the degree of the polynomial. In situations where there is no a priori information on the order of the polynomial, the mathematical model of the process under study is selected, starting with the simplest linear equation, and consequently increasing the degree of the polynomial to obtain an adequate model. The process of obtaining a mathematical model in these situations is as follows. Initially, a full factorial experiment $2^{k}$ or an experiment represented by a fractional replica is implemented, $2^{k-p}$, where $p$ is the number of interaction effects replaced by the new variables.

According to the results of experiments performed in accordance with these plans, the coefficients of the linear regression equation are found. If this equation proves to be inadequate, then the regression coefficients are found for the interaction factors. If the regression equation for the interactions of the factors is also inadequate, then the previously performed experiments supplement the experiments at the "star" points with the shoulder $\alpha$ and experiments at the center of the plan, the number of which is equal $n_{0}$. The number of experiments at "star" points is equal $2 k$. according to the results of 
experiments performed according to the plan $2^{k}$ or $2^{k-p}$ and with additional experiments at the "star" points and at the center of the plan, the second order polynomial coefficients are estimated. It should be noted that the process under study can often be described as a second-order polynomial. If the second-order polynomial is inadequate, proceed to the third-order planning and describe the process under consideration by the third-degree polynomial [1-3].

For five factors, they consider a valuable, second-rate, central composite rotatable plan. In this plan, each variable varies in only three levels: $+1,0,-1$. The use of this plan, which involves only three levels of variation of factors, simplifies and reduces the cost of the experiment [16].

Based on the results of the experiments presented according to the considered plan, the coefficients of the regression equation can be determined

$$
y=b_{0}+b_{1} x_{1}+b_{2} x_{2}+\ldots+b_{k} x_{k}+b_{12} x_{1} x_{2}+\ldots+b_{k-1, k} x_{k-1} x_{k}+b_{11} x_{1}^{2}+\ldots+b_{k k} x_{k}^{2} .
$$

Equation coefficients (2) can be determined using the least squares method, which is one of the basic methods of regression analysis for estimating unknown parameters of regression models by sample data [17].

Thus, the technique is based on the experimental-statistical method of mathematical modeling of the process of the impact of the energy of means of defeat on the armoured obstacle of CAV, in which the experiment is considered as the main source of information about the process, and methods of probability theory and mathematical statistics is considered the main means of processing the results of the experiment.

Experimental studies include a fairly large set of interdependent sequential operations that can be divided into several stages. The logical sequence of the experimental study is shown in fig. 5. It should be noted that the planned experiment can only be successful under a number of conditions.

Firstly, the object of the study should be manageable that is to say it should be possible to unambiguously identify these factors in the selected area and unambiguously determine the relevant responses. In addition, the baseline (responses) should be quantitative and should be measured with any possible combination of selected factor levels. The factors must be independent, unambiguous and compatible. The process under study must be carried out in the entire area of the chosen factor space, that is, in the whole range of change of the selected factors. Furthermore, the researchable object must satisfy the reproducibility requirement of repeatedly repetition of the same experiment, and its responses should have a scatter not exceeding some specified value [14].

Thus, the task is to determine how the impactor will affect the destruction of the armoured obstacle.

These problems can be solved by staging an extreme study. In planning, the following factors were adopted as variables: $v_{f}$ - the speed of the means of defeat, $\mathrm{m} / \mathrm{s} ; \gamma-$ the angle of the indenter meeting with the protective screen, deg.; $h_{f}$ - thickness of the front layer, mm; $h_{r}$ - thickness of the back layer, $\mathrm{mm} ; H$ - hardness of the impactor, HB (300-600 steel U8A); 


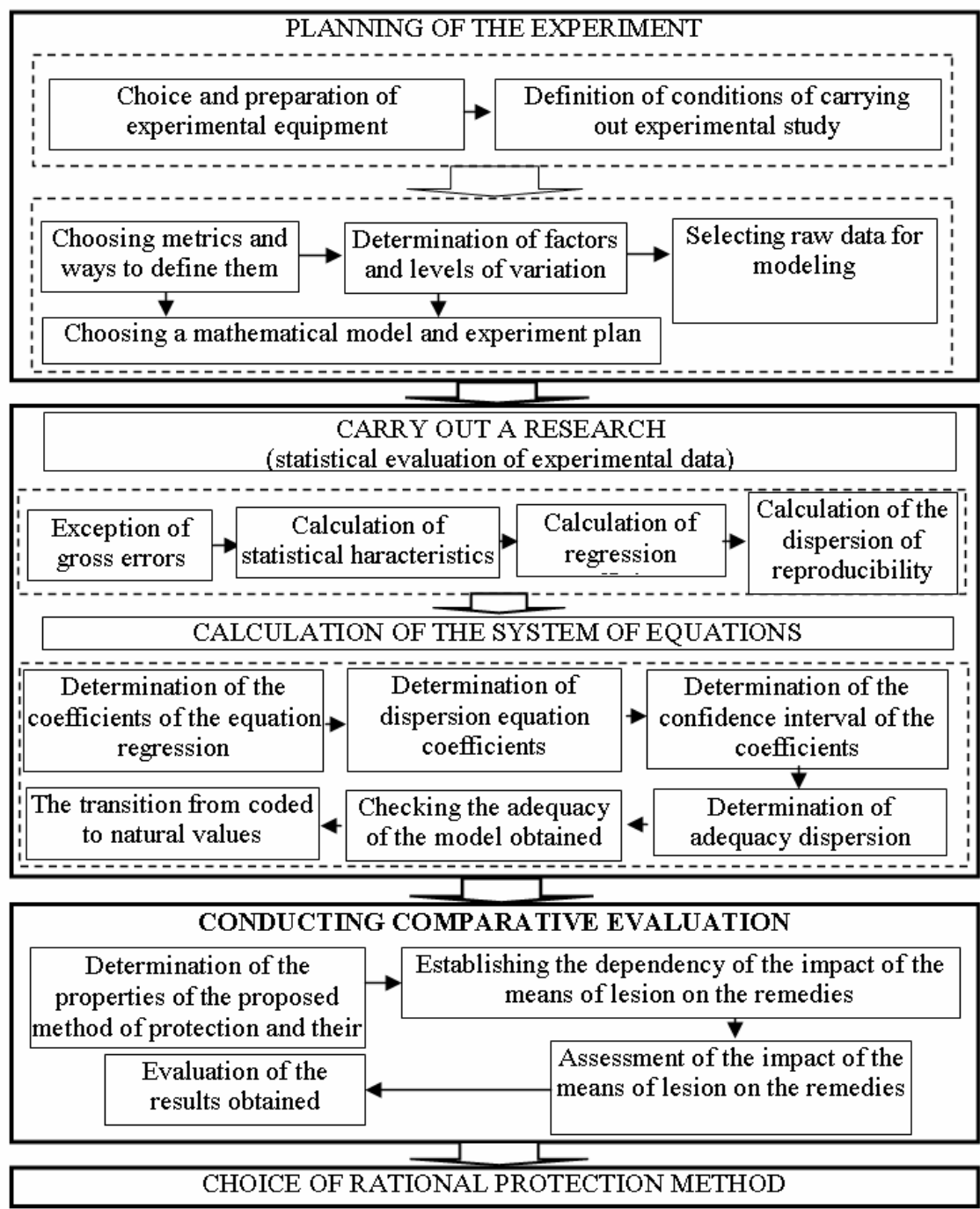

Fig. 5. Structural and logical scheme of the experimental study of the effect of means of lesion on the protective screen of CAV

The impulse deflection of the ballistic pendulum is taken as the optimization parameters. The main levels and intervals of variation of factors [18] are selected by the results of previous experiments, the intervals of variation and levels of factors are given in table 1.

To obtain the model of the process in the form of a second-degree polynomial [19], a central composite second-order rotatable plan is presented, which is presented in table 2 . 
Table 1

Levels and intervals of variation of factors

\begin{tabular}{|l|c|c|c|c|}
\hline \multirow{2}{*}{ Factors } & \multirow{2}{*}{$\begin{array}{l}\text { Variation } \\
\text { intervals }\end{array}$} & \multicolumn{3}{|c|}{ Levels of factors } \\
\cline { 3 - 5 } & 100 & 800 & 900 & 700 \\
\hline $\begin{array}{l}x_{1}-\text { the speed of the means of } \\
\text { defeat } v_{f}, \mathrm{~m} / \mathrm{s}\end{array}$ & 15 & 45 & 60 & 30 \\
\hline $\begin{array}{l}x_{2}-\text { angle of the indenter } \\
\text { meeting with the protective } \\
\text { screen, } \gamma, \text { deg }\end{array}$ & 5 & 10 & 15 & 5 \\
\hline $\begin{array}{l}x_{3}-\text { thickness of the front } \\
\text { layer, } h_{f}, \mathrm{~mm}\end{array}$ & 5 & 10 & 15 & 5 \\
\hline $\begin{array}{l}x_{4}-\text { the thickness of the back } \\
\text { layer, } h_{r}, \text { mm }\end{array}$ & 150 & 450 & 600 & 300 \\
\hline $\begin{array}{l}x_{5}-\text { hardness of the impactor, } \\
H, \mathrm{HB}\end{array}$ & & & & \\
\hline
\end{tabular}

As we can see, the chosen planning matrix satisfies the general properties of the planning matrix, which allows us to quickly calculate the objective function:

symmetry with respect to the zero level, it means that the algebraic sum of the elements of the column of each factor, is equal to zero;

the sum of the squares of the column elements of each of the factors is equal to the number of experiments (property of normalization).

The product of any two different vector columns of factors is zero.

Table 2

Planning matrix

\begin{tabular}{|c|c|c|c|c|c|c|c|}
\hline $\begin{array}{c}\text { Experiment } \\
\text { number }\end{array}$ & $x_{0}$ & $x_{1}$ & $x_{2}$ & $x_{3}$ & $x_{4}$ & $x_{5}$ & $y_{z}$ \\
\hline 1 & + & - & - & - & - & + & 54,6 \\
\hline 2 & + & + & - & - & - & - & 60,2 \\
\hline 3 & + & - & + & - & - & - & 53,3 \\
\hline 4 & + & + & + & - & - & + & 55,4 \\
\hline 5 & + & - & - & + & - & - & 56,7 \\
\hline 6 & + & + & - & + & - & + & 58,9 \\
\hline 7 & + & - & + & + & - & + & 59,4 \\
\hline 8 & + & + & + & + & - & - & 50,3 \\
\hline 9 & + & - & - & - & + & - & 51,4 \\
\hline 10 & + & + & - & - & + & + & 52,7 \\
\hline 11 & + & - & + & - & + & + & 58,9 \\
\hline 12 & + & + & + & - & + & - & 57,2 \\
\hline 13 & + & - & - & + & + & + & 56,4 \\
\hline 14 & + & + & - & + & + & - & 56,8 \\
\hline 15 & + & - & + & + & + & - & 55,7 \\
\hline 16 & + & + & + & + & + & + & 57,4 \\
\hline 17 & + & +2 & 0 & 0 & 0 & 0 & 58,5 \\
\hline
\end{tabular}




\begin{tabular}{|c|c|c|c|c|c|c|c|}
\hline 18 & + & -2 & 0 & 0 & 0 & 0 & 54,1 \\
\hline 19 & + & 0 & +2 & 0 & 0 & 0 & 58,3 \\
\hline 20 & + & 0 & -2 & 0 & 0 & 0 & 53,1 \\
\hline 21 & + & 0 & 0 & +2 & 0 & 0 & 58,8 \\
\hline 22 & + & 0 & 0 & -2 & 0 & 0 & 53,9 \\
\hline 23 & + & 0 & 0 & 0 & +2 & 0 & 59,7 \\
\hline 24 & + & 0 & 0 & 0 & -2 & 0 & 53,2 \\
\hline 25 & + & 0 & 0 & 0 & 0 & +2 & 56,2 \\
\hline 26 & + & 0 & 0 & 0 & 0 & -2 & 53,6 \\
\hline 27 & + & 0 & 0 & 0 & 0 & 0 & 54,3 \\
\hline 28 & + & 0 & 0 & 0 & 0 & 0 & 55,8 \\
\hline 29 & + & 0 & 0 & 0 & 0 & 0 & 53,6 \\
\hline 30 & + & 0 & 0 & 0 & 0 & 0 & 55,2 \\
\hline 31 & + & 0 & 0 & 0 & 0 & 0 & 56,1 \\
\hline 32 & + & 0 & 0 & 0 & 0 & 0 & 54,7 \\
\hline
\end{tabular}

The variances of the predicted values of the optimization parameter are the same at equal distances from the zero level (the rotatability property of the planning matrix).

The coefficients of the given equation (2), with the number of factors $k=5$ and the kernels of the plan represented by $2^{5-1} \quad\left(1=x_{1} x_{2} x_{3} x_{4} x_{5}\right)$, are determined using formulas of the form:

$$
\begin{gathered}
b_{0}=\frac{A}{N}\left[2 \lambda^{2}(k+2) \sum_{j=1}^{N} y_{j}-2 \lambda c \sum_{i=1}^{k} \sum_{j=1}^{N} x_{i j}^{2} y_{j}\right] \\
b_{i}=\frac{c}{N} \sum_{j=1}^{N} x_{i j} y_{j} \\
b_{i l}=\frac{c^{2}}{N \lambda} \sum_{j=1}^{N} x_{i j} x_{l j} y_{j} \\
b_{i i}=\frac{A}{N}\left\{c^{2}[(k+2) \lambda-k] \sum_{j=1}^{N} x_{i j}^{2} y_{j}+c^{2}(1-\lambda) \sum_{i=1}^{k} \sum_{j=1}^{N} x_{i j}^{2} y_{j}-2 \lambda c \sum_{j=1}^{N} y_{j}\right\} .
\end{gathered}
$$

To find the regression equation coefficients in the first stage of experimental data processing, we find the sums of the equation $(3-6)$ [20-21]

$$
\begin{gathered}
\sum_{j=1}^{32} y_{i}=1784 ; \sum_{j=1}^{32} x_{1 j} y_{j}=11,3 ; \sum_{j=1}^{32} x_{2 \mathrm{j}} y_{j}=10,3 ; \sum_{j=1}^{32} x_{3 j} y_{j}=17,7 ; \\
\sum_{j=1}^{32} x_{4 j} y_{j}=10,7 ; \sum_{j=1}^{32} x_{5 j} y_{j}=17,3 ; \sum_{j=1}^{32} x_{1 j} x_{2 j} y_{j}=-16,5 ; \sum_{j=1}^{32} x_{1 j} x_{3 j} y_{j}=-12,1 ; \\
\sum_{j=1}^{32} x_{1 j} x_{4 j} y_{j}=0,9 ; \sum_{j=1}^{32} x_{1 j} x_{5 j} y_{j}=-12,3 ; \sum_{j=1}^{32} x_{2 j} x_{3 j} y_{j}=-11,9 ;
\end{gathered}
$$




$$
\begin{gathered}
\sum_{j=1}^{32} x_{2 j} x_{4 j} y_{j}=23,9 ; \sum_{j=1}^{32} x_{2 j} x_{5 j} y_{j}=17,1 ; \sum_{j=1}^{32} x_{3 j} x_{4 j} y_{j}=4,3 ; \\
\sum_{j=1}^{32} x_{3 j} x_{5 j} y_{j}=13,1 ; \sum_{j=1}^{32} x_{4 j} x_{5 j} y_{j}=-3,5 ; \sum_{j=1}^{32} x_{1 j}^{2} y_{i}=1346 ; \sum_{j=1}^{32} x_{2 j}^{2} y_{j}=1341 \\
\sum_{j=1}^{32} x_{3 j}^{2} y_{j}=1346 ; \sum_{j=1}^{32} x_{4 j}^{2} y_{j}=1347 \sum_{j=1}^{32} x_{5 j}^{2} y_{j}=1335 ; \sum_{i=1}^{5} \sum_{j=1}^{32} x_{i j}^{2} y_{j}=6714 .
\end{gathered}
$$

The next step is to determine the value

$$
\begin{gathered}
A=\frac{1}{2 \lambda[(k+2) \lambda-k]}=0,4929, \\
c=\frac{N}{\sum_{j=1}^{N} x_{i j}^{2}}=1,333, \\
\lambda=\frac{k\left(n_{c}+n_{0}\right)}{(k+2) n_{c}}=0,879120879 .
\end{gathered}
$$

After some calculations, equations $(3-6)$ will take the form

$$
\begin{gathered}
b_{0}=10,82 \sum_{j=1}^{32} y_{j}-2,344 \sum_{i=1}^{5} \sum_{j=1}^{32} x_{i j}^{2} y_{i}, \\
b_{i}=0,042 \sum_{j=1}^{32} x_{i j} y_{j}, \\
b_{i l}=0,063194444 \sum_{j=1}^{32} x_{i j} x_{l j} y_{j}, \\
b_{i i}=0,0316 \sum_{j=1}^{32} x_{i j}^{2} y_{j}+0,0033 \sum_{i=1}^{5} \sum_{j=1}^{32} x_{i j}^{2} y_{j}-0,0361 \sum_{\mathrm{j}=1}^{32} y_{j} .
\end{gathered}
$$

Substituting the sums obtained into formulas (7-10), we find the values of the regression equation coefficients for the pendulum deflection impulse.

Based on the coefficients obtained, the equation (2) will take the form

$$
\begin{aligned}
y_{z} & =54,946389+0,4708 x_{1}+0,4292 x_{2}+0,7375 x_{3}+0,4458 x_{4}+0,7208 x_{5}- \\
& -1,04271 x_{1} x_{2}-0,76465 x_{1} x_{3}+0,05688 x_{1} x_{4}-0,77729 x_{1} x_{5}-0,75201 x_{2} x_{3}+ \\
& +1,51035 x_{2} x_{4}+1,08063 x_{2} x_{5}+0,27174 x_{3} x_{4}+0,82785 x_{3} x_{5}-0,22118 x_{4} x_{5}+ \\
& +0,30863 \mathrm{x}_{1}^{2}+0,156963 \mathrm{x}_{2}^{2}+0,321269 \mathrm{x}_{3}^{2}+0,346546 \mathrm{x}_{4}^{2}-0,04526 x_{5}^{2} .
\end{aligned}
$$

The dispersion of the coefficients of the regression equation can be found using the formula

$$
s^{2}\left\{b_{0}\right\}=\frac{2 A \lambda^{2}(k+2)}{N} s_{y}^{2},
$$




$$
\begin{gathered}
s^{2}\left\{b_{i}\right\}=\frac{c}{N} s_{y}^{2}, \\
s^{2}\left\{b_{i l}\right\}=\frac{c^{2}}{\lambda N} s_{y}^{2}, \\
s^{2}\left\{b_{i i}\right\}=\frac{A c^{2}[(k+1) \lambda-(k-1)]}{N} s_{y}^{2} .
\end{gathered}
$$

Accordingly, the dispersion of the coefficients will be equal

$$
\begin{aligned}
& s^{2}\left\{b_{0}\right\}=0,1667 s_{y}^{2}, \\
& s^{2}\left\{b_{i}\right\}=0,0417 s_{y}^{2}, \\
& s^{2}\left\{b_{i l}\right\}=0,0632 s_{y}^{2}, \\
& s^{2}\left\{b_{i i}\right\}=0,0349 s_{y}^{2} .
\end{aligned}
$$

The dispersion $s^{2}\left\{y_{z}\right\}$ of the optimization parameter is determined by the results of experiments in the center of the plan (table 3):

Table 3

Auxiliary table for calculating the dispersion $s^{2}\left\{y_{z}\right\}$

\begin{tabular}{|c|c|c|c|c|}
\hline $\begin{array}{c}\text { The number of } \\
\text { the study }\end{array}$ & $y_{z u}$ & $\bar{y}_{z}$ & $y_{z u}-\bar{y}_{z}$ & $\left(y_{z u}-\bar{y}_{z}\right)^{2}$ \\
\hline 27 & 54,3 & & $-0,65$ & 0,4225 \\
\hline 28 & 55,8 & & 0,85 & 0,7225 \\
\hline 29 & 53,6 & \multirow{5}{*}{54,95} & $-1,35$ & 1,8225 \\
\hline 30 & 55,2 & 0,25 & 0,0625 \\
\hline 31 & 56,1 & & 1,15 & 1,3225 \\
\hline 32 & 54,7 & & $-0,25$ & 0,0625 \\
\hline$n n n y y$ & & & \multirow{2}{*}{$S_{E}=\sum_{z=1}^{6}\left(y_{z u}-\bar{y}_{z}\right)^{2}=4,415$} \\
\hline$\sum_{u=1}^{6} y_{z u}=329,7$ & & & & \\
\hline
\end{tabular}

$$
s^{2}\left\{y_{z}\right\}=\frac{\sum_{u=1}^{6}\left(y_{z u}-\bar{y}_{z}\right)^{2}}{n_{0}-1}=0,883,
$$

where $n_{0}=6$ the number of the studies in the center of plan.

The dispersion of the coefficients of the regression equation $y_{z}$ are determined using the formulas (15-18):

$$
\begin{gathered}
s^{2}\left\{b_{0}\right\}=0,00096278 ; s^{2}\left\{b_{i}\right\}=0,00024069 ; s^{2}\left\{b_{i l}\right\}=0,00036505 ; \\
s^{2}\left\{b_{i i}\right\}=0,00020165 .
\end{gathered}
$$


Mean square errors in the determination of the regression coefficients for $y_{z}$ respectively equal

$$
\begin{gathered}
s\left\{b_{0}\right\}=0,3836231 ; s\left\{b_{i}\right\}=0,1918115 ; s\left\{b_{i l}\right\}=0,2362217 ; \\
s\left\{b_{i i}\right\}=0,1755655 .
\end{gathered}
$$

We define the confidence intervals for the coefficients:

$$
\begin{gathered}
\Delta b_{0}= \pm t s\left\{b_{0}\right\}= \pm 2,57 \times 0,3836231= \pm 0,985911313 ; \\
\Delta b_{i}= \pm t s\left\{b_{i}\right\}= \pm 0,492955656 ; \\
\Delta b_{i 1}= \pm t s\left\{b_{i l}\right\}= \pm 0,607089785 ; \Delta b_{i i}= \pm t s\left\{b_{i i}\right\}= \pm 0,451203305 .
\end{gathered}
$$

Coefficients that, according to the absolute value of less than the corresponding confidence intervals, can be considered statistically insignificant and excluded from the regression equation [22]. The result of rotatable planning of the regression equation is written in the form

$$
\begin{aligned}
y_{z} & =54,946389+0,4708 x_{1}+0,4292 x_{2}+0,7375 x_{3}+0,4458 x_{4}+0,7208 x_{5}- \\
& -1,04271 x_{1} x_{2}-0,76465 x_{1} x_{3}+0,05688 x_{1} x_{4}-0,77729 x_{1} x_{5}-0,75201 x_{2} x_{3}+ \\
& +1,51035 x_{2} x_{4}+1,08063 x_{2} x_{5}+0,27174 x_{3} x_{4}+0,82785 x_{3} x_{5}-0,22118 x_{4} x_{5}+ \\
& +0,30863 \mathrm{x}_{1}^{2}+0,156963 \mathrm{x}_{2}^{2}+0,321269 \mathrm{x}_{3}^{2}+0,346546 \mathrm{x}_{4}^{2}-0,04526 x_{5}^{2} .
\end{aligned}
$$

To determine $s_{\text {ad }}^{2}$ we should calculate the sum $s_{R}$ f squares of deviations of the calculated $y_{z j}$ values of the response function from experimental ones $y_{z j}$ at all points in the plan (table 4).

The number of degrees of freedom is determined by the formula

$$
f=N-k^{\prime}-\left(n_{0}-1\right)=9 \text {, }
$$

where $k^{\prime}$ the number of statistically significant coefficients of the model; $N-$ the total number of experiments; $n_{0}$ - the total number of experiments at the center of the plan.

The dispersion of adequacy is determined by equation

$$
s_{\text {ad }}^{2}=\frac{s_{R}-s_{E}}{f}=3,745723
$$

The adequacy of the obtained model is verified by $F$ - criterion:

$$
F_{p}=\frac{s_{\mathrm{ad}}^{2}}{s_{y}^{2}}=4,242041899,
$$

where $s_{\mathrm{ad}}^{2}$ - the dispersion of adequacy; $s_{y}^{2}$ - the dispersion of the optimization parameter. 
Table 4

Auxiliary table for calculating $s_{R}$

\begin{tabular}{|c|c|c|c|c|}
\hline $\begin{array}{c}\text { Experiment } \\
\text { number }\end{array}$ & $y_{z j}$ & $y_{z j}$ & $y_{z j}-y_{z j}$ & $\left(y_{z j}-y_{z j}\right)^{2}$ \\
\hline 1 & 0,33 & 0,28 & 0,05 & 0,0025 \\
\hline 2 & 0,47 & 0,45 & 0,02 & 0,0004 \\
\hline 3 & 0,52 & 0,55 & $-0,03$ & 0,0009 \\
\hline 4 & 0,34 & 0,33 & 0,01 & 0,0001 \\
\hline 5 & 0,71 & 0,65 & 0,06 & 0,0036 \\
\hline 6 & 0,35 & 0,35 & 0,00 & 0,0000 \\
\hline 7 & 0,77 & 0,63 & 0,14 & 0,0196 \\
\hline 8 & 1,64 & 1,79 & $-0,15$ & 0,0225 \\
\hline 9 & 0,50 & 0,42 & 0,08 & 0,0064 \\
\hline 10 & 0,29 & 0,28 & 0,01 & 0,0001 \\
\hline 11 & 0,51 & 0,36 & 0,17 & 0,0289 \\
\hline 12 & 0,20 & 0,35 & $-0,15$ & 0,0225 \\
\hline 13 & 0,31 & 0,26 & 0,05 & 0,0025 \\
\hline 14 & 0,74 & 0,72 & 0,02 & 0,0004 \\
\hline 15 & 0,81 & 0,83 & $-0,02$ & 0,0004 \\
\hline 16 & 0,42 & 0,41 & 0,01 & 0,0001 \\
\hline 17 & 0,54 & 0,44 & 0,10 & 0,0100 \\
\hline 18 & 0,54 & 0,69 & $-0,15$ & 0,0225 \\
\hline 19 & 0,65 & 0,60 & 0,05 & 0,0025 \\
\hline 20 & 0,28 & 0,38 & $-0,10$ & 0,0100 \\
\hline 21 & 0,95 & 0,96 & $-0,01$ & 0,0001 \\
\hline 22 & 0,31 & 0,35 & $-0,04$ & 0,0016 \\
\hline 23 & 0,23 & 0,27 & $-0,04$ & 0,0016 \\
\hline 24 & 0,57 & 0,58 & $-0,01$ & 0,0001 \\
\hline 25 & 0,15 & 0,33 & $-0,18$ & 0,0324 \\
\hline 26 & 0,72 & 0,59 & 0,13 & 0,0169 \\
\hline 27 & 0,25 & 0,19 & 0,06 & 0,0036 \\
\hline 28 & 0,25 & 0,18 & 0,07 & 0,0049 \\
\hline 29 & 0,25 & 0,33 & $-0,08$ & 0,0064 \\
\hline 30 & 0,25 & 0,27 & $-0,02$ & 0,0004 \\
\hline 31 & 0,25 & 0,19 & 0,06 & 0,0036 \\
\hline 32 & 0,25 & 0,35 & $-0,10$ & 0,0100 \\
\hline & & & & $s_{R}=\sum_{j=1}^{32}\left(y_{z j}-y_{z j}\right)^{2}=0,2342$ \\
\hline
\end{tabular}


Thus, the mathematical model in which $s_{y}^{2}$ is accepted as $s^{2}\left\{y_{z}\right\}=0.883$, the value of the criterion $F=4,242$. Tabular value of $F_{T}$ - criterion at $5 \%$ significance level, in particular degrees of freedom for the numerator 9 and for the denominator 5 is equal to 4,85 . The value $F_{p}<F_{T}$, therefore, the resulting model can be considered adequate.

The transition from coded $\left(x_{1}, x_{2}, x_{3}, x_{4}, x_{5}\right)$ to natural $\left(v_{f}, \gamma, h_{f}, h_{r}, H\right)$ values of the factors is carried out in accordance with the experimental conditions (table 1) by the formulas

$$
x_{1}=\frac{v_{f}-800}{100} ; x_{2}=\frac{\gamma-45}{15} ; x_{3}=\frac{h_{f}-10}{5} ; x_{4}=\frac{h_{r}-10}{5} ; x_{5}=\frac{H-450}{150} .
$$

Thus, using the mathematical model obtained from the experimental data, we can construct the following dependencies.

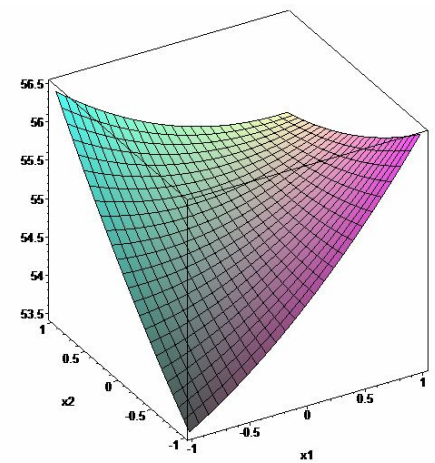

(a)

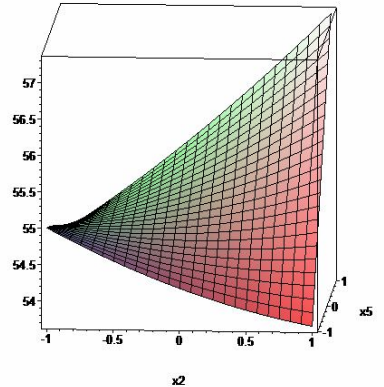

(c)

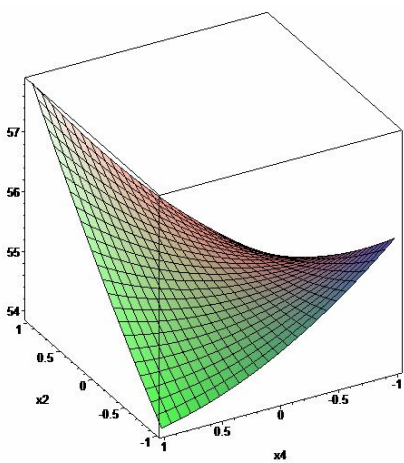

(b)

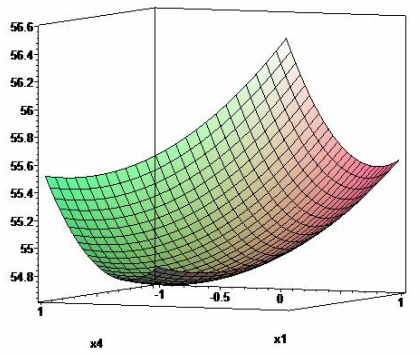

(d)

Fig. 5. Dependence of the pendulum deflection pulse (a) from the speed of the impactor and the angle of the protective screen (b) from the tilt angle of the protective screen and the thickness of the back layer (c) from the tilt angle of the protective screen and the hardness of the impactor (d) from the thickness of the back layer and the speed of the impactor 


\section{Conclusions}

Analyzing the pattern of impact of the means of lesion on the protective screen revealed by the multivariate experiment, we can conclude that the parameters of the means of the lesion in one way or another affect on the protective screen. That is, the means of lesion can break through this protective screen, but during its penetration by the impactor is lost the amount of energy that is not enough in the future to break through the main armoured obstacle.

Thus, using of a protective screen will protect the CAV from breaking through the main armoured obstacle. It should also be noted that as the thickness of the protective screen increases, the weight of the CAV will increase, which will result in loss of buoyancy and decrease in other CAV characteristics..

In the future, it is necessary to carry out an experimental study taking into account the sixth factor - the rigidity of the elastic element. Based on theoretical and experimental data on the impact of the means of lesion on the armoured obstacle, it is necessary to develop recommendations on the choice of a rational method of protection of CAV.

\section{REFERENCES}

1. Zazhigaev, L. S. Kish'yan, A. A., Romanikov, YU. I. Methods of planning and processing the results of a physical experiment. - Moscow: Atomizdat Publ, 1978. - 232 p. (in Russian)

2. Adler, YU. P. Markova, E. V. Granovskii, YU. V. Planning an experiment to find the best conditions. - Moscow: Nauka Publ, 1976. - 280 p. (in Russian)

3. Spirin, N. A. Lavrov, V. V. Methods of planning and processing the results of an engineering experiment. - Yekaterinburg: GOU VPO UGTU. Publ, 2004. - 257 p.

4. Slyvins 'kyi, O.A. Chernozubenko, O.V. Problems of manufacturing welded armoured corps of domestic combat armoured vehicles // Slyvins'kyi, O.A. Bisyk, S.P. Chepkov, I.B. Vasyl'kivskyi, M.I. Weapons and military equipment. - 2017. - no 3(15), pp. 29-38. (in Ukraine)

5. Maystrenko, A.L. Increasing the protection of combat armored vehicles against the defeat of 12.7-mm B-32 bullets // Maystrenko, A.L. Kushch, V.I. Kulych, V.H. Neshpor O.V Bisyk, S.P. Weapons and military equipment. - 2017, - no 1(13), pp. 18-23. (in Ukraine)

6. Zhang Yiben, Experimental and numerical investigations on low-velocity impact response of high strength steel/composite hybrid plate. // Zhang Yiben, Sun Lingyu, Li Lijun, Wang Taikun, Shen Le. International Journal of Impact Engineering. - 2019, - vol. 123, p. 1-13. (in China)

7. Kostyuk V.V. Evaluation of increasing the level of protection of multi-purpose vehicles. // Kostyuk V.V. Rusilo P.O. Kalinin O.M. Budyanu R.H. Varvanets Yu.V. Visnyk NTU«KHPI». - 2014, - no14 (1057), p. 1-9. (in Ukraine)

8. Johnson, N. Lyon, F. Statistics and experimental design in engineering and science: Experimental design methods (translated from English edited by Letskoi E. K., Markova E. V.). Moscow: Mir Publ, - 1981. - 520 p. (in Russian)

9. Astanin $V . V$. Application of ballistic pendulum for impact strength studies of materials // Astanin V. V. Olefir H. O. Technology-intensive, Kyiv: NAU - 2009. - no 2, pp. 19-24. (in Ukraine)

10. DSTU 3975-2000. Protection of armored specialized vehicles. General technical requirements: [Effective from 2001-01-01]. -K.: Gosstandart of Ukraine, - 2000. - 18 p. (in Ukraine)

11. Patent 130778 Ukraine, International Patent Classification (2018) F41J11/00. The device that is for conducting ballistic tests (in Ukraine) / Dachkovskyi V.O., Datsenko I.P., Kotsiuruba V.I., Sakhno V.P., Siedov S.H., Bublii V.A.; - the applicant and patent owner DACHKOVSKYI V.O.- № u201806591; statement. 12.06.2018; publ. 26.12.2018; bulletin № 24 . 
12. Patent 132190 Ukraine, International Patent Classification (2009) F41H5/04. Protective screen of combat armoured vehicles (in Ukraine) / Dachkovskyi V.O., Kurovska T.YU., Sampir O.M. - the applicant and patent owner Dachkovskyi V.O. - № u201809885; statement 03.10.2018; publ. 11.02.2019; bulletin № 3/2019.

13. Barabashchuk, V.I. Kredentser, B.P., Miroshnichenko V.I. Planning an experiment in technology. Kyiv: Tekhnika Publ., - 1984. - 200 p. (in Ukraine)

14. Muhachyov, V.A. Planning and processing of experimental results. Tomsk: Tomsk State University of Control Systems and Radioelectronics, 2007. 118 p. (in Russian)

15. Lavrenchik,V.N. Setting up a physical experiment and statistical processing of its results. Moscow: Enerhoatomizdat Publ., 1986. 272 p. (in Russian)

16. J. Thomas. Visual Analytics Solution for Scheduling Processing Phases // J. Thomas, B. Belaton, A.T. Khader, Jasttian. Intelligent Computing \& Optimization - 2018. - vol. 866, pp. 395-408. (in Thailand)

17. A.V. Azarov. Improving the Computational Model for Approximation of Particle Functions over Diameter of Dust in the Work Area and at the Border of the Sanitary Protection Zone // A.V. Azarov, N.S. Zhukova, V.F. Sidorenko. Procedia Engineering, - 2016. - vol.150, pp.. 2073 - 2079 (in Russian)

18. A.V. Azarov Obtaining mathematical models for assessing efficiency of dust collectors using integrated system of analysis and data management statistica Design of Experiments // A.V. Azarov, N.S. Zhukova, E.Yu. Kozlovtseva, D.R. Dobrinsky. Journal of Physics: Conference Series. - 2018 - ser. 5678, pp. 1-7. (in Russian)

19. E. Tutunina. Optimization of Parameters and Operation Modes of the Heat Pump in the Environment of the Low-Temperature Energy Source, // Evgenia Tutunina, Alexey Vaselyev, Sergey Korovkin, Sergey Senkevich International Conference on Intelligent Computing \& Optimization, - 2019. vol. 866. pp 497-504 (in Russian)

20. Adriana-Simona Mihaita. Motorway Traffic Flow Prediction using Advanced Deep Learning, // Adriana-Simona Mihaita, Haowen Li, Zongyang He, Marian-Andrei Rizoiu. Intelligent Transportation Systems Conference (ITSC), - 2019. pp. 1683-1690 (in Australia)

21. Wenqi Ju, On some geometric problems of color-spanning sets // Wenqi Ju, Chenglin Fan, Jun Luo, Binhai Zhu, Ovidiu Daescu. Journal of Combinatorial Optimization, - 2012. vol. 6681, pp 113-124 (in Singapore)

22. A.V. Kudryashov. Study of specific requirements for LED lighting, // A.V. Kudryashov. IOP Conference Series: Materials Science and Engineering, - 2018. vol. 451. pp. 1-4. (in Russian)

Стаття надійшла 21.01.2020

Дачковський В.О., Даценко І.П., Кочюруба В.І., Яльницький О.Д., Голда О.Л., Неділько О.М., Сиротенко А.М.

\section{ЕКСПЕРИМЕНТАЛЬНЕ ДОСЛІДЖЕННЯ ВПЛИВУ ЗАСОБІВ УРАЖЕННЯ НА} ЗАХИСНІ ЕКРАНИ БОЙОВИХ БРОНЬОВАНИХ МАШИН

Для оцінки відносних властивостей захисного екрана до уражаючої енергії засобів ураження було проведено експериментальне дослідження, яке дозволило перевірити гіпотезу щодо захисту бойових броньованих машин від засобів ураження, на які діє кінетична енергія, засобів ураження. На підставі даних, отриманих під час експериментального дослідження, була побудована математична модель, яка описує імпульс удару ударника у захисний екран. Використання цієї моделі дає можливість розрахувати втрати енергії викликаної деформацією та руйнуванням перешкоди. Побудований в результаті багатофакторного експерименту математична модель описує вплив засобів ураження на захисний екран із врахуванням швидкості засобів ураження, кута нахилу захисного екрану, товщини переднього і заднього шару і твердості засобів ураження.

Ключові слова: бойові броньовані машини, захисні екрани, експериментальне дослідження, математична модель. 


\section{УДК 355.41}

Дачковський В.О., Даченко І.П., Кочюруба В.І., Яльнищький О.Д., Голда О.Л., Неділько О.М., Сиротенко А.М. Експериментальне дослідження впливу засобів ураження на захисні екрани бойових броньованих машин // Опір матеріалів і теорія споруд: наук.-тех. збірн. К.: КНУБА, 2020. - Вип. 104. - С. 117-135.

Для очінки відносних властивостей захисного екрана до уражаючої енергії засобів ураження було проведено експериментальне дослідження, яке дозволило перевірити гіпотезу щодо захисту бойових броньованих машин від засобів ураження, на які діє кінетична енергія, засобів ураження. На підставі даних, отриманих під час експериментального дослідження, була побудована математична модель, яка описує імпульс удару ударника у захисний екран. Використання иієї моделі дає можливість розрахувати втрати енергї викликаної деформачією та руйнуванням перешкоди. Побудований в результаті багатофакторного експерименту математична модель описує вплив засобів ураження на захисний екран із врахуванням швидкості засобів ураження, кута нахилу захисного екрану, товщиини переднього $і$ заднього шару і твердості засобів ураження.

Іл. 5. Бібліог. 22 назв.

\section{UDC 355.41}

Dachkovskyi V.O., Datsenko I.P., Kotsiuruba V.I., Yalnytskyi O.D., Holda O.L., Nedilko O.M., Syrotenko A.M. Experimental investigation of impact of injury measures on the protection screens of combat armoured vehicles // Strength of Materials and Theory of Structures: Scientificand-technical collected articles - Kyiv: KNUBA, 2020. - Issue 104. - P. 117-135.

In order to evaluate the relative properties of the protective screen to the striking energy of the means of defeat, an experimental study was conducted, which allowed to test the hypothesis regarding the protection of the combat armoured vehicles against the means of defeat which, under the action of kinetic energy, destroy the armoured obstacle.. Based on the data obtained during the experimental study, a mathematical model was constructed that describes the punching momentum of the protective screen.. The use of this model makes it possible to calculate the energy losses caused by deformation and destruction of the obstacle. Built as a result of the multifactor experiment, the regularity of the impact of the means of defeat on the protective screen takes into account the speed of the means of defeat, the angle of encounter of the means of defeat with the protective screen, the thickness of the front and back layer and the hardness of the means of defeat.

Fig. 5. Ref. 22

Автор (вчена ступень, вчене звання, посада): кандидат технічних наук, доцент кафедри технічного забезпечення Національного університету оборони України імені Івана Черняховського, ДАЧКОВСЬКИЙ Володимир Олександрович

Адреса робоча: 03049 , м. Київ, Повітрофлотський проспект, 28, Національний університет оборони України імені Івана Черняховського

Робочий тел.: +38 044 271-09-36, факс +38 044 271-06-97 03680

Мобільний тел.: +38(067) 422-21-75

E-mail: 1903vova@ukr.net

ORCID ID: https://orcid.org/0000-0003-1480-5021

Автор (вчена ступень, вчене звання, посада): кандидат технічних наук, докторант Національного університету оборони України імені Івана Черняховського, ДАЦЕНКО Іван Петрович

Адреса робоча: 03049 , м. Київ, Повітрофлотський проспект, 28, Національний університет оборони України імені Івана Черняховського

Робочий тел.: +38 044 271-06-97, факс +38 044 271-06-97 03680

Мобільний тел.: +38(050) 722-46-45

E-mail: docik_ivan@i.ua

ORCID ID: https://orcid.org/0000-0002-0047-413X 
Автор (вчена ступень, вчене звання, посада): доктор технічних наук, доцент, професор кафедри оперативного та бойового забезпечення Національного університету оборони України імені Івана Черняховського, КОЦЮРУБА Володимир Іванович

Адреса робоча: 03049, м. Київ, Повітрофлотський проспект, 28, Національний університет оборони України імені Івана Черняховського.

Робочий тел.: +38 044 271-06-97, факс +38 044 271-06-97 03680 .

Мобільний тел.: +38(050) 833-31-90,

E-mail: kotcuru@ukr.net

ORCID ID: https://orcid.org/0000-0001-6565-9576

Автор (вчена ступень, вчене звання, посада): кандидат технічних наук, доцент кафедри технічного забезпечення Національного університету оборони України імені Івана Черняховського, ЯЛЬНИЦЬКИЙ Олег Дмитрович

Адреса робоча: 03049, м. Київ, Повітрофлотський проспект, 28, Національний університет оборони України імені Івана Черняховського

Робочий тел.: +38 044 271-09-36, факс +38 044 271-06-9703680

Мобільний тел.: +38(097) 358-59-06

E-mail: bimcha@ukr.net

ORCID ID: https://orcid.org/0000-0001-9246-2250

Автор (вчена ступень, вчене звання, посада): кандидат військових наук, доцент кафедри сухопутних військ Національного університету оборони України імені Івана Черняховського, ГОЛДА Олександр Леонідович

Адреса робоча: 03049, м. Київ, Повітрофлотський проспект, 28, Національний університет оборони України імені Івана Черняховського

Мобільний тел.: +38(098) 406-27-26

E-mail: rainbow15@i.ua

ORCID ID: https://orcid.org/0000-0002-2050-3428

Автор (вчена ступень, вчене звання, посада): кашдидат технічних наук, доцент, провідний науковий співробітник науково-методичного центру організації наукової та науковотехнічної діяльності Національного університету оборони України імені Івана Черняховського, НЕДІЛЬКО Олександр Миколайович

Адреса робоча: 03049, м. Київ, Повітрофлотський проспект, 28, Національний університет оборони України імені Івана Черняховського.

Робочий тел.: +38 044 271-06-92, факс +38 044 271-06-97 03680.

Мобільний тел.: +38(093) 256-49-34,

E-mail: Nedilko1962@gmeil.com

ORCID ID: http://orcid.org/0000-0001-8080-0486

Автор (вчена ступень, вчене звання, посада): доктор військових наук, начальник Національного університету оборони України імені Івана Черняховського, СИРОТЕНКО Анатолій Миколайович

Адреса робоча: 03049, м. Київ, Повітрофлотський проспект, 28, Національний університет оборони України імені Івана Черняховського.

Робочий тел.: +38044248 1077

Мобільний тел.: +38 (067) 40558 36, +38 (050) 1495727

E-mail: a.syrotenko1960@gmail.com

ORCID ID: http://orcid.org/0000-0002-0266-5706 